\title{
Prenatal Immune Challenge Alters the Hypothalamic-Pituitary-Adrenocortical Axis in Adult Rats
}

\author{
Johannes M. H. M. Reul, Ingemar Stec, G. Jan Wiegers, Marta S. Labeur, Astrid C. E. Linthorst, Eduardo Arzt, \\ and Florian Holsboer \\ Max Planck Institute of Psychiatry, Clinical Institute, Department of Neuroendocrinology, 80804 Munich, Federal Republic of Germany
}

\begin{abstract}
We investigated whether non-abortive maternal infections would compromise fetal brain development and alter hypothalamic-pituitary-adrenocortical (HPA) axis functioning when adult. To study putative teratogenic effects of a $\mathrm{T}$ cell-mediated immune response versus an endotoxic challenge, 10- $d$-pregnant rats received a single intraperitoneal injection of $5 \times 10^{8}$ human red blood cells (HRBC) or gram-negative bacterial endotoxin (Escherichia coli LPS: $30 \mu \mathrm{g} / \mathrm{kg}$ ). The adult male progeny (3 mo old) of both experimental groups showed increased basal plasma corticosterone levels. In addition, after novelty stress the HRBC group, but not the LPS group, showed increased ACTH and corticosterone levels. Both groups showed substantial decreases in mineralocorticoid (MR) and glucocorticoid receptor (GR) levels in the hippocampus, a limbic brain structure critical for HPA axis regulation, whereas GR concentrations in the hypothalamus were unchanged and in anterior pituitary were slightly increased. HRBC and LPS indeed stimulated the maternal immune system as revealed by specific anti-HRBC antibody production and enhanced IL-1 $\beta$ mRNA expression in splenocytes, respectively. This study demonstrates that a $T$ cell-mediated immune response as well as an endotoxic challenge during pregnancy can induce anomalies in HPA axis function in adulthood. Clinically, it may be postulated that disturbed fetal brain development due to prenatal immune challenge increases the vulnerability to develop mental illness involving inadequate responses to stress. (J. Clin. Invest. 1994. 93:2600-2607.) Key words: T cell-mediated immune response • endotoxic challenge $\bullet$ pregnancy $\bullet$ corticosteroid receptor $\bullet$ brain development
\end{abstract}

\section{Introduction}

It has been known for many years that maternal infection associated with severe systemic illness can cause abortion, perinatal mortality, and fetal resorption (1-3). Since the fetus is regarded by the maternal immune system as an allograft, a delicate immune balance is maintained at the maternal-fetal interface. Locally, the maternal immune responses are tightly controlled by cytokines of maternal and fetal origin $(4,5)$. Intraperitoneal

Address correspondence to Dr. Johannes M. H. M. Reul, Max-PlanckInstitute of Psychiatry, Clinical Institute, Department of Neuroendocrinology, Kraepelinstrasse 2-10, D-80804 Munich, FRG.

Received for publication 29 October 1993 and in revised form 4 February 1994.

J. Clin. Invest.

(C) The American Society for Clinical Investigation, Inc.

0021-9738/94/06/2600/08 $\$ 2.00$

Volume 93, June 1994, 2600-2607 (i.p. $)^{1}$ injection of high doses of LPS or cytokines, such as IL-2, in pregnant rats produces cytotoxic lymphocyte invasion, fetal necrosis, and abortion $(6,7)$, presumably due to a disturbance of this immune balance. However, in those cases (clinical or experimental) in which no abortion takes place, few data are available whether the offspring will suffer from any teratogenic consequences.

Cytokines act as mediators of systemic acute phase responses which are characterized by rapidly induced changes in endocrinologic, metabolic, immunologic, and neurologic functions $(8,9)$. These alterations include induction of fever $(9,10)$, hypotension (11), hepatic synthesis of acute phase proteins (12), inhibition of the hypothalamic-pituitary-gonadal axis (13), and behavioral changes $(14,15)$. Cytokines such as interleukin-1 (IL-1) also stimulate hypothalamic-pituitary-adrenocortical (HPA) axis activity $(16,17)$ leading to elevated levels of glucocorticoid hormones, which suppress the immune response (18). This circuit between immune system and HPA axis has been considered as an immuno-endocrine feedback loop (19).

Glucocorticoid hormones play a pivotal role in the maintenance of homeostasis and a tight regulation of their secretion is herein of utmost importance. The activity of the HPA system is regulated by two corticosteroid receptors in the brain, which can be distinguished as mineralocorticoid (MR) and glucocorticoid receptors (GR) (20). MR has a distinct neuroanatomical localization with highest concentrations in the pyramidal and dentate gyrus neurons of the hippocampus $(21,22)$. In contrast, GR shows a ubiquitous distribution in the brain with high levels in the paraventricular nucleus of hypothalamus and in the hippocampus, where these receptors seem to be colocalized with MR $(21,22)$. Functionally, limbic (hippocampal) MR is involved in the regulation of the basal HPA axis activity, presumably by a tonic trans-synaptic influence on the composition and quantities of corticotrophin secretagogues in the hypothalamic-hypophyseal system. Brain and hypophyseal GR mediate the feedback signal of elevated glucocorticoid levels after stress or at the circadian peak of adrenocortical secretion (20, $23,24)$. In concert, MR and GR are involved in the homeostatic control of the HPA system and consequently, a tight regulation of these receptor sites is of principal importance. Hence, a decline in hippocampal corticosteroid receptor levels has been found often to be associated with a hyperactivity of the HPA system $(24,25)$.

We started a study to investigate whether maternal immune stimulation affects fetal brain development and causes an altered HPA axis when adult. As immunostimulants, human red

1. Abbreviations used in this paper: $\mathrm{ADX}$, adrenalectomy; $\mathrm{CBG}$, corticosterone binding globulin; GR, glucocorticoid receptor; HPA, hypothalamic-pituitary-adrenocortical; HRBC, human red blood cells; i.p., intraperitoneal; MR, mineralocorticoid receptor. 
blood cells (HRBC) and LPS were used. LPS is a rather unspecific immunostimulant acting primarily by direct stimulation of macrophages, B cells and other cell types. In contrast, HRBC activate the immune system specifically via $T$ cell-dependent mechanisms (26). Therefore, the use of different immunostimulants permits the study of prenatal immune stimulation via alternative ( $T$ cell-independent and $T$ cell-dependent) pathways, producing different time courses of maternal cytokine release, elevated adrenocortical secretion and other hormonal factors (27-29). This approach may allow discrimination between different immune challenges on fetal brain development.

\section{Methods}

Animals and prenatal treatment. Timed-pregnant primiparous Wistar rats were purchased from Charles River Wiga (Sulzfeld, Germany) and arrived in our animal room on their sixth day of pregnancy. The day on which a vaginal plug was noted was defined as the first day of gestation. Dams were housed singly under standard lighting (lights on from $0600-2000 \mathrm{~h})$ and temperature $\left(23^{\circ} \mathrm{C}\right)$ conditions. Food and water were available ad libitum.

On day 10 of gestation, relatively early in fetal rat brain development (30), these dams received a single i.p. injection of either $30 \mu \mathrm{g} / \mathrm{kg}$ LPS or $5 \times 10^{8} \mathrm{HRBC}$ between 10:00 and 11:00 a.m.. LPS (Escherichia coli 026:B6; Sigma Chemical Co., St. Louis, MO) was dissolved in sterile pyrogen-free saline $(9 \mu \mathrm{g}$ LPS/300 $\mu \mathrm{l})$. For HRBC, blood was collected in sterile citrate-coated tubes, centrifuged, and the leucocytes were aspirated. Next, the erythrocytes were washed three times with saline and resuspended to a concentration of $5 \times 10^{8} \mathrm{HRBC}$ in $300 \mu \mathrm{l}$ saline. Control dams received an i.p. injection of $300 \mu \mathrm{l}$ saline.

Gestation lasted for 20-22 d. After birth, male and female pups were counted and litters were reduced to 10 pups per mother to guarantee similar feeding conditions. The pups were weaned at $3 \mathrm{wk}$ and any female pups were removed from the cage. Only male rats were used for further experimentation. These rats were housed six per cage under above mentioned conditions and used for experimentation when the age of 3 mo was reached.

In a separate set of experiments, the response of the maternal immune system after antigenic stimulation was verified. Thereto, 10-dpregnant rats were i.p. injected with HRBC or LPS and killed after $18 \mathrm{~d}$ or $3 \mathrm{~h}$, respectively. Control pregnant rats received an i.p. saline injection. For further experimental details, see below.

Measurement of anti-HRBC antibodies in plasma of $H R B C$-treated pregnant rats. 10-d-pregnant rats were injected i.p. with $5 \times 10^{8} \mathrm{HRBC}$ or vehicle (pyrogen-free sterile saline) between 10:00 and 11:00 a.m. 18 $\mathrm{d}$ after injection, rats were quickly anesthetized with halothane, decapitated, and trunk blood was collected in ice-chilled EDTA-coated tubes. Anti-HRBC antibody content in plasma was measured by a whole cell ELISA as developed by Dr. Wolfgang Klinkert (Max Planck Institute of Psychiatry, Theoretical Institute, Department of Neuroimmunology, Martinsried, Germany). Thereto, microtiter plates (Costar Corp., Cambridge, MA) were coated with a poly-D-lysine solution $(1 \mathrm{mg} / 100$ $\mathrm{ml} \mathrm{H}_{2} \mathrm{O}$ ) for $2 \mathrm{~h}$ at room temperature. Next, washed HRBC (from the same person from which HRBC were collected for immunization of the rats) were added to each well $(200,000 /$ well $)$ and the plates were centrifuged at $400 \mathrm{~g}$ for $5 \mathrm{~min}$. After removal of the supernatant, HRBC were fixed with $0.2 \%$ glutaraldehyde for $15 \mathrm{~min}$ at room temperature, washed two times with PBS, blocked with casein for $30 \mathrm{~min}$ at $37^{\circ} \mathrm{C}$, and washed again two times with PBS. Subsequently, diluted test plasmas $(50 \mu \mathrm{l} /$ well $)$ were added and incubated for $1 \mathrm{~h}$ at room temperature. After the incubation, wells were washed twice with PBS and endogenous peroxydase activity was blocked with $\mathrm{H}_{2} \mathrm{O}_{2}$ in methanol (166 $\mu \mathrm{l} / 50 \mathrm{ml}$ methanol; $15 \mathrm{~min}$ at room temperature) after which the wells were washed four times with PBS. Next, peroxydase-labeled goat anti- rat antibody (DIANOVA, Hamburg, FRG; 1:1,000 dilution in PBS; 50 $\mu \mathrm{l} /$ well; this antibody recognizes total IgG and IgM) was added for $1 \mathrm{~h}$ at room temperature) after which the wells were washed twice with PBS. Finally, $50 \mu$ l substrate solution (ABTS; 2,4-Azino-bis-[3-Ethylbenzthiazolin-6-sulfonacid]), diammoniumsalt in substrate buffer $(0.1$ $\mathrm{M}$ citric acid, $0.1 \mathrm{M} \mathrm{Na}_{2} \mathrm{HPO}_{4}$; $\mathrm{pH} 4.3$; concentration ABTS: $25 \mathrm{mg} / 50$ $\mathrm{ml}$ buffer), and $3.4 \mu \mathrm{l} \mathrm{H}_{2} \mathrm{O}_{2}$ were added, and optical density was measured at $405 \mathrm{~nm}$ in a microtiter plate reader.

Northern blot analysis of $I L-1 \beta \quad m R N A$ in splenocytes of LPStreated pregnant rats. 10-d-pregnant rats were injected i.p. with $30 \mu \mathrm{g} /$ $\mathrm{kg} \mathrm{LPS}$ or vehicle (pyrogen-free sterile) saline between 10:00 and 11:00 a.m. $3 \mathrm{~h}$ after injection, spleens were aseptically removed under halothane (Hoechst, Frankfurt am Main, Germany) anesthesia and dispersed through a screen cloth (pore size $40 \mu \mathrm{m}$ ) to obtain single-cell suspensions. Next, cells were centrifuged $\left(10 \mathrm{~min} \times 400 \mathrm{~g}, 4^{\circ} \mathrm{C}\right)$, the pellet resuspended in lysis buffer ( $155 \mathrm{mM} \mathrm{NH}_{4} \mathrm{Cl}, 10 \mathrm{mM} \mathrm{KHCO}_{3}, 0.1$ mM EDTA) and maintained on ice for $6 \mathrm{~min}$ to lyse erythrocytes. Cells were separated from erythrocyte fragments by low-speed centrifugation $\left(20 \mathrm{~min} \times 50 \mathrm{~g}, 4^{\circ} \mathrm{C}\right.$ ) through fetal calf serum (FCS) (GIBCO, Paisley, Scotland). From the cell pellet, total spleen lymphocyte RNA was isolated according to the method of Chomczynski and Sacchi (31). Subsequent electrophoresis, blotting, radiolabeling of the rat IL-1 $\beta$ probe, and hybridization were performed as described by Sambrook et al. (32). Briefly, $20 \mu \mathrm{g}$ RNA was separated on a $1 \%$ agarose formaldehyde denaturing gel and, next, blotted onto nylon membranes (Hybond N; Amersham, Braunschweig, Germany) by pressure blotting. The rat IL- $1 \beta$ clone which was inserted in a SK+ Bluescript vector (Stratagene, La Jolla, CA), was a gift from Dr. Dan Lindholm (Max Planck Institute of Psychiatry, Theoretical Institute, Department of Neurochemistry, Martinsried, Germany) and comprised $\sim 500 \mathrm{bp}$. The plasmid was linearized with HindIII, and a ${ }^{32} \mathrm{P}$-labeled $\mathrm{cRNA}$ probe was produced by in vitro transcription (Stratagene) with T3 polymerase and $\alpha-{ }^{32} \mathrm{P}$ UTP. Control hybridizations were performed with a $\beta$-actin cDNA probe which was generated from a $1-\mathrm{kb} \beta$-actin cDNA Pstl fragment. This probe was labeled with a random-priming kit (Boehringer Mannheim, Mannheim, Germany) using $\alpha-{ }^{32} \mathrm{P}$-dCTP (Amersham). Nylon membranes were prehybridized for $4 \mathrm{~h}$ at $42^{\circ} \mathrm{C}$ in a solution containing $50 \%$ formamide, $5 \times$ sodium chloride sodium phosphate EDTA buffer (SSPE), $5 \times$ Denhardt's solution, $0.1 \%$ SDS and $100 \mu \mathrm{g} / \mathrm{ml}$ denatured salmon sperm DNA and then hybridized with the probe at the same temperature for $15 \mathrm{~h}$. Blots were washed at increasing salt and temperature stringency with a final wash in $0.1 \times$ SSC containing $1 \%$ SDS for 2 $\mathrm{h}$ at $65^{\circ} \mathrm{C}$ or $30 \mathrm{~min}$ at $60^{\circ} \mathrm{C}$ for the IL- $1 \beta$ cRNA and $\beta$-actin cDNA probe, respectively. Dried filters were exposed to Kodak XAR-5 film with an intensifying screen for $2-4 \mathrm{~d}$ at $-70^{\circ} \mathrm{C}$. The size of the bands were estimated by comparison with $18 \mathrm{~S}$ and $28 \mathrm{~S}$ ribosomal RNA. The blot was reprobed after eluting the first probe with $5 \mathrm{mM}$ Tris/HCL $\mathrm{pH}$ 8.0, $2 \mathrm{mM}$ EDTA, $0.1 \times$ Denhardt's solution, for $2 \mathrm{~h}$ at $70^{\circ} \mathrm{C}$. After the previous signal was removed, the blot was prehybridized and hybridized according to the method described above.

Neuroendocrine experiments on prenatally immune-stimulated rats. Each experimental and control group was composed of animals derived of at least six pregnant rats. For estimation of the basal plasma levels of ACTH and corticosterone, great care was taken to keep the rats undisturbed the night before the experiment. All neuroendocrine experiments were performed between 7:00 and 9:00 a.m. Rats were individually anaesthetized $(<25 \mathrm{~s})$ in a glass jar containing saturated halothane vapor after which the animals were decapitated immediately. Trunk blood was collected in ice-chilled EDTA-coated $(10 \mathrm{ml})$ tubes containing $140 \mu \mathrm{g}$ aprotinin (Trasylol, Bayer, Germany).

The responses in plasma ACTH and corticosterone to a mild stressor were assessed by exposing rats to a novel environment stress procedure. Undisturbed rats were placed singly in a new cage for 30 min, after which they were quickly anaesthetized, decapitated, and trunk blood was collected as outlined above. Plasma samples for ACTH and corticosterone measurement by radioimmunoassay (RIA ICN Biomedicals, Costa Mesa, CA), were stored at -80 and $-20^{\circ} \mathrm{C}$, respectively. The inter- and intraassay coefficient of variance for 
ACTH, were 7 and 5\%, respectively, with a detection limit of $\sim 2$ $\mathrm{pg} / \mathrm{ml}$. For corticosterone, the inter- and intraassay coefficient of variance was 7 and $4 \%$, respectively, with a detection limit of 0.15 $\mu \mathrm{g} / 100 \mathrm{ml}$

Surgery and ${ }^{3} \mathrm{H}$-steroid binding assay on tissues of prenatally immune-stimulated rats. For corticosteroid binding measurement, rats were bilaterally adrenalectomized under halothane anaesthesia to deplete their body of endogenous corticosteroids. After surgery, the animals were maintained on $0.9 \% \mathrm{NaCl}$ in the drinking water. Immediately after removal from the body, adrenal glands were carefully cleaned, placed in an eppendorf tube (adrenals of one rat per tube), and frozen on dry ice. The weight of the adrenals was determined on the same day as the day of surgery to prevent unreliable adrenal weight data due to water loss from the tissue during long-term storage at $-80^{\circ} \mathrm{C}$. In addition, the rats were weighed at the time of adrenalectomy (ADX).

One day after ADX, rats were quickly anaesthetized with halothane after which they were decapitated immediately. Trunk blood was collected in pre-chilled EDTA-coated tubes and the plasma was checked for the absence of any endogenous corticosterone by RIA (ICN Biomedicals). Immediately after decapitation, the brain and the pituitary were rapidly removed from the skull. Subsequently, the anterior part of the pituitary was separated from the neurointermediate lobe and the hippocampus and hypothalamus were dissected from the brain. Dissected tissues were instantaneously frozen on dry ice and stored at $-80^{\circ} \mathrm{C}$ until corticosteroid receptor assay.

Brain or pituitary tissues were homogenized (100 mg brain tissue/ $\mathrm{ml} ; 50 \mathrm{mg}$ anterior pituitary tissue/ml; 10 strokes at $900 \mathrm{rpm}$ ) in icecold $5 \mathrm{mM}$ Tris- $\mathrm{HCl}$, pH 7.4, containing, $5 \%$ glycerol, $10 \mathrm{mM}$ sodium molybdate, $1 \mathrm{mM}$ EDTA, and $2 \mathrm{mM} \beta$-mercaptoethanol using a glass homogenizer with a Teflon pestle milled at a clearance of $0.25 \mathrm{~mm}$ on the radius. The homogenate was centrifuged at $100,000 \mathrm{~g}$ for $60 \mathrm{~min}$ at $0-2^{\circ} \mathrm{C}$ to obtain cytosol (i.e., supernatant fraction). All reagents used were analytical grade. For saturation analysis, aliquots of cytosol (100 $\mu$ ) of pooled hippocampus (from 6-8 rats per group) were incubated with a range of ${ }^{3} \mathrm{H}$-labeled steroid concentration $(0.1-10 \mathrm{nM} ; 6-8$ concentrations; total volume $150 \mu \mathrm{l})$ in duplicate. Measurements on individual hippocampi and pooled hypothalami and anterior pituitaries were done in quintuplicate at a single concentration (15 nM), giving $>95 \%$ saturation of binding (33-35). Measurement of receptors in individual hypothalami and anterior pituitaries was not conducted since these tissues are too small to obtain sufficient cytosol for reliable receptor measurements. Receptor measurements on pooled tissues were repeated at least three times to ensure collection of reproducible data. Determination of corticosterone binding globulin (CBG) was performed in plasma of individual animals diluted 1 in 10 , with $25 \mathrm{nM}$ $\left[{ }^{3} \mathrm{H}\right]$ corticosterone (total binding) and $25 \mathrm{nM}\left[{ }^{3} \mathrm{H}\right]$ corticosterone + $1,000 \times$ corticosterone (nonspecific binding) determined in quintuplicate.

Total binding to soluble macromolecules in cytosol was determined with $\left[{ }^{3} \mathrm{H}\right]$ aldosterone (87-94 Ci/mmol, NEN DuPont, Dreieich, Germany) or with $\left[{ }^{3} \mathrm{H}\right]$ dexamethasone (85-106 Ci/mmol, Amersham). For measurement of MR, total binding was assessed by incubating cytosol with $\left[{ }^{3} \mathrm{H}\right]$ aldosterone in the presence of a 100 -fold excess of the specific glucocorticoid RU 28362 (11 $\beta, 17 \beta$-dihydroxy-6-methyl-17 $\alpha$ (1-propionyl)androsta-1,4,6-triene-3-one). Unlabeled RU 28362 was included to prevent $\left[{ }^{3} \mathrm{H}\right]$ aldosterone from binding to $\mathrm{GR}$, so that only binding of this ${ }^{3} \mathrm{H}$-ligand to MR was measured. Nonspecific binding was determined in parallel incubations containing a 1,000-fold excess of corticosterone in addition to cytosol and $\left[{ }^{3} \mathrm{H}\right]$ aldosterone. Total binding for the GR was determined by incubating cytosol with $\left[{ }^{3} \mathrm{H}\right]-$ dexamethasone. Since $\left[{ }^{3} \mathrm{H}\right]$ dexamethasone also displays considerable affinity for MR (36; I. Stec and J. M. H. M. Reul, unpublished observation), the fraction of $\left[{ }^{3} \mathrm{H}\right]$ dexamethasone binding to $M R$ was estimated by including a 100-fold excess of RU 28362 in parallel incubation tubes. Nonspecific binding was determined in parallel incubations containing a 1,000-fold excess of dexamethasone in addition to cytosol and $\left[{ }^{3} \mathrm{H}\right]$-dexamethasone.
After incubation for $20-24 \mathrm{~h}$ at $0^{\circ} \mathrm{C}$, bound and free ${ }^{3} \mathrm{H}$-steroid were separated by Sephadex LH-20 (Pharmacia, Sweden) gel filtration (100 $\mu \mathrm{l}$ of the cytosol- ${ }^{3} \mathrm{H}$-steroid mixture was applied to the LH-20 columns) and radioactivity was measured in a liquid scintillation counter. The protein concentration was determined by the method of Lowry (37) with BSA as the standard. The binding data were expressed as femtomoles per $\mathrm{mg}$ protein and nonspecific binding was subtracted from total binding to yield specific binding. In this manner, the MR concentration could be directly measured. However, GR binding was estimated by subtraction of the specific binding of $\left[{ }^{3} \mathrm{H}\right]$ dexamethasone $+100 \times$ RU 28362 from the specific binding of $\left[{ }^{3} \mathrm{H}\right]$ dexamethasone. $\left[{ }^{3} \mathrm{H}\right]$-dexamethasone $+100 \times \mathrm{RU} 28362$ rather than $\left[{ }^{3} \mathrm{H}\right]$-aldosterone $+100 \times$ RU 28362 binding data were used to estimate the amount of the specific $\left[{ }^{3} \mathrm{H}\right]$-dexamethasone binding to $M R$, because $\left[{ }^{3} \mathrm{H}\right.$ ]dexamethasone $+100 \times \mathrm{RU} 28362$ binding to $\mathrm{MR}$ was found to be $\sim 30 \%$ less than $\left[{ }^{3} \mathrm{H}\right.$ ]aldosterone $+100 \times$ RU 28362 binding to this receptor type (I. Stec and J. M. H. M. Reul, unpublished observation). The maximal number of binding sites $\left(B_{\max }\right)$ and relative binding affinity $\left(K_{d}\right)$ were determined by Scatchard and Woolf analysis.

These experimental protocols were approved by the Government of Bavaria, FRG.

Data analysis. The experimental data on litter size, secondary sex ratio, body weight, adrenal weight and receptor binding measurements were tested for statistically significant differences with oneway analysis of variance (ONEWAY) followed by Duncan multiple range test in appropriate cases. Statistically significant differences in plasma hormone levels were investigated with the two-tailed Mann-Whitney Utest. Data were considered to be statistically different when $P<0.05$. This was corrected by Bonferroni procedure when multiple comparisons were performed.

\section{Results}

Effect of antigenic challenge on the maternal immune system. To verify whether an antigenic challenge with HRBC or LPS would stimulate the immune system of pregnant rats, the presence of anti-HRBC antibodies in plasma of HRBC inoculated dams and IL- $1 \beta$ mRNA expression in spleen lymphocytes after LPS injection was determined.

In the whole cell ELISA with HRBC as the antigenic substrate, it was found that plasma of HRBC-injected dams produced substantially higher optical density values at plasma dilutions ranging from $1: 1$ to $1: 160$ as compared with values obtained with serum from saline-injected dams or rat control plasma (Fig. 1). Thus, antigenic stimulation of pregnant rats with xenogeneic blood cells produced an immune response giving rise to the production of specific antibodies directed against this antigen.

Fig. 2 shows that, $3 \mathrm{~h}$ after i.p. LPS injection, spleen lymphocytes of pregnant rats expressed markedly increased levels of IL- $1 \beta$ mRNA, which is observed on the blot as a single band with a length of $\sim 1.8 \mathrm{~kb}$. IL- $1 \beta$ mRNA in the saline-injected dams was hardly detectable, although similar amounts of total RNA were analyzed in each lane as confirmed by the signal of the $\beta$-actin mRNA content (Fig. 2).

Effect of immune stimulation during pregnancy on numeral and physical parameters of the offspring. At birth, no significant differences were found in the total number of progeny per dam (Table I). However, dams injected with HRBC during pregnancy gave birth to fewer male pups than the control dams, as revealed by the significant decrease of $15 \%$ in the secondary sex ratio (male births/total births) (Table I). The number of females per litter was not different among the experimental groups. At the time of birth, there were no differences in 


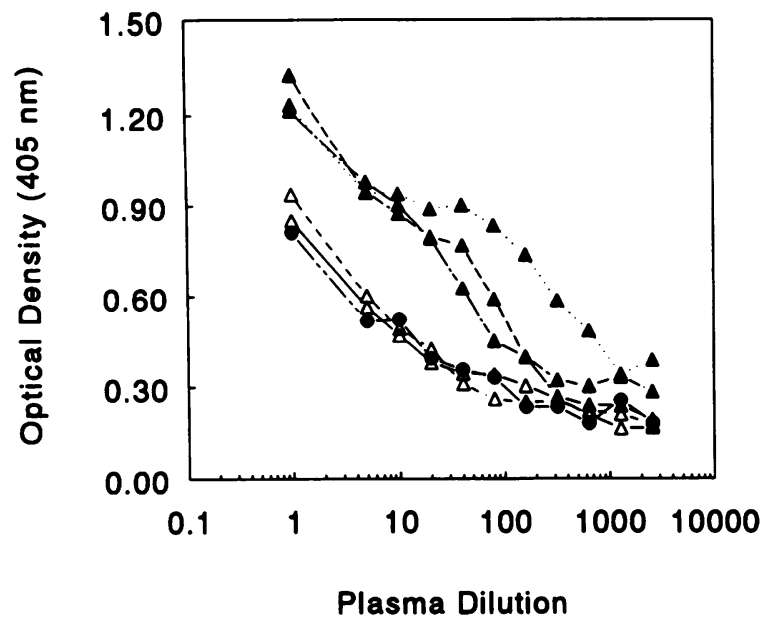

Figure 1. Measurement of anti-HRBC antibodies in plasma of rats after injection of HRBC during pregnancy. 10-d-pregnant rats were i.p. injected with $5 \times 10^{8} \mathrm{HRBC}$ or saline and killed after $18 \mathrm{~d}$. Antibodies directed against HRBC were measured in plasma using a whole cell ELISA method. Data are expressed as the optical density at $405 \mathrm{~nm}$ of ELISA measurements on 1:1 to 1:2,500 diluted plasma of HRBC-treated dams ( $\Delta)$, saline-treated dams $(\Delta)$, and on plasma dilutions of normal control rats (๑). Details on the ELISA method are described in Methods. Data are shown of three HRBC-injected rats, two saline-injected animals, and one normal control rat. Each data point represents the mean of triplicate measurements. This figure shows a specific anti-HRBC antibody response in pregnant rats injected with HRBC but not in saline-injected controls. In addition, optical densities obtained with plasma from saline-injected pregnant rats did not differ from that of rat control plasma. Incubations with the (second) peroxydase-coupled antibody in the absence of any experimental plasma produced only background levels of optical density $(\sim 0.16)$ in the ELISA.

body weight between the pups of either sex (data not shown). The male offspring at the age of 3 mo did not show any differences in either body weight or adrenal weight (Table I).

Effect of prenatal immune challenge on HPA axis activity in the adult offspring. To test whether the prenatal antigen treatment had a permanent influence on adult HPA system activity, we determined plasma ACTH and corticosterone both under basal conditions and after stress. Early morning basal plasma corticosterone levels were significantly elevated in both LPS $(+67 \%)$ and $\mathrm{HRBC}(+122 \%$; Fig. $3 \mathrm{~B})$ groups. Most circulating corticosterone is bound to $\mathrm{CBG}$ and albumin but no significant differences were found in CBG levels (control, $1.13 \pm 0.04 \mu \mathrm{M}$; LPS, $1.07 \pm 0.03 \mu \mathrm{M}$; HRBC, $1.10 \pm 0.03 \mu \mathrm{M}$, mean \pm SEM, $n$ $=7$ ), indicating that in both LPS and HRBC groups free corticosterone levels were elevated. Basal plasma levels of ACTH were not elevated (Fig. $3 A$ ). To examine whether challenged rats respond differently to stress, we used a mild stress paradigm (30 min in a novel environment). The HRBC group showed much larger increases in plasma levels of ACTH $(+73 \%)$ and corticosterone $(+57 \%)$ than the control animals. The LPS rats showed HPA hormone responses to stress which were not significantly different from the controls (Figs. 3, C and $D$ ).

Effect of prenatal immune challenge on brain and hypophyseal corticosteroid receptor levels. To assess whether corticosteroid receptor changes may be involved in the observed neuroendocrine changes, we measured the concentration of MR and

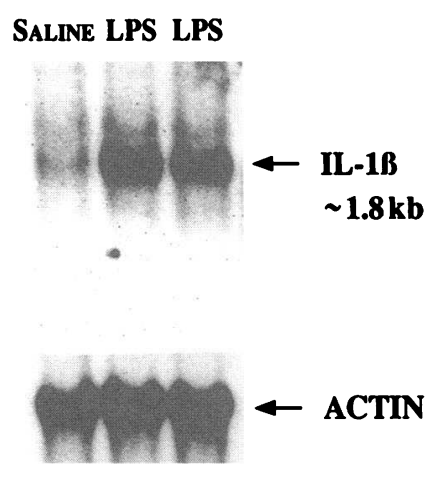

Figure 2. IL-1 $\beta$ mRNA expression in spleen lymphocytes of pregnant rats after LPS injection. Northern blot of RNA (20 $\mu \mathrm{g}$ total RNA per lane) extracted from spleen lymphocytes of pregnant rats killed 3 $\mathrm{h}$ after i.p. LPS ( $30 \mu \mathrm{g} / \mathrm{kg}$ body weight) or saline injection. Each lane represents analysis of pooled spleen lymphocyte RNA from two rats. (Upper panel) After hybridizing with a 500 bp ${ }^{32} \mathrm{P}$-labeled rat IL- $1 \beta$

cRNA at $42^{\circ} \mathrm{C}$ and washing at high stringency, the autoradiograms were revealed after $4 \mathrm{~d}$ of exposure. A hybridizing band of $1.8 \mathrm{~kb}$ indicates markedly higher expression of IL- $1 \beta$ mRNA in spleen lymphocytes of pregnant rats at $3 \mathrm{~h}$ after LPS as compared to the expression in saline-treated controls. After complete elution, the same blot was reprobed with a ${ }^{32} \mathrm{P}$-labeled rat $\beta$-actin cDNA (lower panel). The filter was hybridized and washed as above and exposed for $2 \mathrm{~d}$. The signal intensity of the $\beta$-actin mRNA demonstrates that virtually equal amounts of RNA were loaded in each lane.

GR in the hippocampus, and levels of GR in hypothalamus and anterior pituitary of the prenatally immune-stimulated rats. As shown in Fig. $4 A$ and $C$, both LPS and HRBC led to a decrease of $20-30 \%$ in MR levels in pooled as well as in individually measured hippocampus tissue of the adult offspring. A decline in hippocampal GR levels of $\sim 15 \%$ was also evident in both treated groups (Fig. 4, $B$ and $C$ ). Saturation binding and Scatchard analysis (Figs. 4, $A$ and $B$ ) revealed no changes in the $K_{\mathrm{d}}$ of either MR or GR. Hypothalamic GR levels were unchanged, and those in the anterior pituitary slightly increased $(+13 \%$; Table II $)$.

\section{Discussion}

This study shows for the first time that an immune challenge during pregnancy affects fetal brain development which manifests in a disturbed HPA axis persisting into adult life. Hence, both types of prenatal immune stimulation led in the male offspring to an increase in basal corticosterone values, and, in addition, confrontation of the prenatally HRBC-treated rats to a psychological stress situation led to an augmented response in plasma ACTH and corticosterone levels. Moreover, these changes in hormonal secretion were accompanied by marked decreases in the concentration of MR and GR in the hippocampus, a limbic brain structure critical for processing of stress and HPA axis regulation.

We observed that injection of LPS or HRBC in 10-d-pregnant rats produced inflammatory and immune responses, as revealed by the increased expression of IL- $1 \beta$ mRNA in spleen lymphocytes and the production of specific anti-HRBC antibodies, respectively. These observations confirm that the immune system of the pregnant animals responded to the antigenic challenge. As outlined in the introduction, the acute phase response of an immune reaction involves many changes in metabolism, endocrine system, immune system and brain In the present study, one of these pathophysiological responses or combination of responses may have affected the develop- 


\begin{tabular}{|c|c|c|c|}
\hline & \multicolumn{3}{|c|}{ Prenatal treatment } \\
\hline & Control & LPS & HRBC \\
\hline \multicolumn{4}{|l|}{ Offspring } \\
\hline Total ôô + $९$ per dam & $13.3 \pm 0.5(28)$ & $14.7 \pm 0.7(17)$ & $13.5 \pm 0.5(25)$ \\
\hline Ratio o births/total births & $0.52 \pm 0.02(28)$ & $0.52 \pm 0.04(17)$ & $0.44 \pm 0.02(25)^{*}$ \\
\hline \multicolumn{4}{|l|}{ Male offspring ( 3 mo old) } \\
\hline Body weight (g) & $514 \pm 10[10]$ & $520 \pm 15[8]$ & $531 \pm 9[11]$ \\
\hline Adrenal weight (mg) & $36.7 \pm 1.7[10]$ & $39.5 \pm 0.7[8]$ & $34.7 \pm 1.1[11]$ \\
\hline
\end{tabular}

Data on the offspring of each experimental group concern the total number of ơ $+\uparrow q$ per dam and the secondary sex ratio (male births/total births, mean \pm SEM), based on 17-28 litters per experimental group as denoted between parentheses. The physical data (mean \pm SEM) on the adult male offspring are body weight (expressed as grams) and adrenal weight (expressed as mg per two adrenals) of 8-11 animals (denoted between brackets), derived randomly from 8-11 different litters. In this experiment, 10-d-pregnant rats received a single i.p. injection of either $30 \mu \mathrm{g} / \mathrm{kg}$ LPS or $5 \times 10^{8} \mathrm{HRBC}$ between 10:00 and 11:00 a.m. Control dams received a saline injection. After birth, male and female pups were counted in each litter and the secondary sex ratio determined. Body and adrenal weight of the male offspring were determined at the age of 3 mo. ${ }^{*} P<0.05$, Duncan multiple range test.

ment of the fetal brain, resulting in a disturbed HPA axis function when adult. In this respect, the following mechanisms may be involved.

(a) The action of newly synthetized cytokines after HRBC inoculation may have perturbed the delicate immune balance maintained at the feto-maternal interface. Antigens such as HRBC are thought to produce cell-mediated and humoral immune responses involving $T$-helper $1\left(T_{H} 1\right)$ and $T_{H} 2$ cells, re-
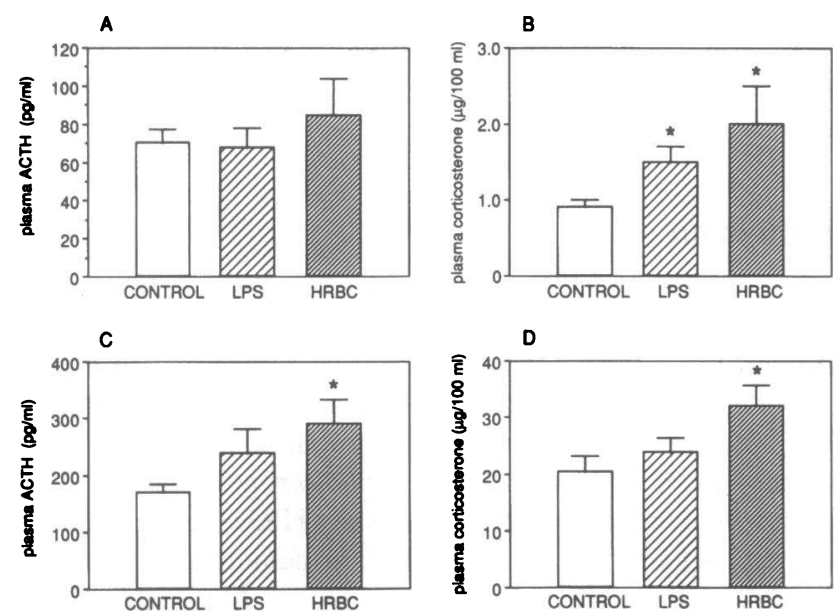

Figure 3. Plasma levels of ACTH and corticosterone under early morning basal resting conditions $(A$ and $B)$ and after 30 min novel environment stress $(C$ and $D)$ in LPS and HRBC groups (mean \pm SEM, $n=7-9$ ). Each experimental and control group was composed of animals derived of at least six pregnant rats. For estimation of the basal plasma levels of ACTH and corticosterone, great care was taken to keep the rats ( 3 mo old) undisturbed during the night before the experiment. All neuroendocrine experiments were performed between 7:00 and 9:00 a.m. After decapitation, trunk blood was collected in ice-chilled EDTA-coated $(10 \mathrm{ml})$ tubes containing $140 \mu \mathrm{g}$ aprotinin. Changes in ACTH and corticosterone in response to psychological stress were determined by placing undisturbed rats singly in a "new" cage for $30 \mathrm{~min}$, after which they were decapitated and trunk blood was collected as outlined above. Plasma ACTH and corticosterone were measured by RIA. Differences between means were tested with the Mann-Whitney U-test. ${ }^{*}, P<0.025$. spectively. $T_{H} 1$ cells produce cytokines, such as IL- 2, IFN- $\gamma$, and TNF- $\beta,(38,39)$ which are harmful for the maintenance of the feto-placental unit (40), whereas $T_{H^{2}}$-derived cytokines (IL-4, IL-5, IL-6 [interleukins involved in B cell development; 41] IL-10) are not (42). $T_{H} 1$ cytokines are thought to cause fetal demise by induction of natural killer activity and stimulation of cytotoxic lymphocyte development (42). According to Wegmann et al. (42), the maternal immune system displays enhanced humoral immune responses and suppressed cell-mediated immunity to prevent synthesis of $T_{H} 1$ cytokines. The $T_{H} 2$ cytokine IL- 10 suppresses cytokine synthesis by $T_{H} 1$ cells $(38,41,42)$. However, despite this apparent shift in the maternal immune system from cell-mediated immunity towards humoral responses, HRBC administration produced effects which were detrimental for the developing fetal brain. IL-1, IL-6, and TNF- $\alpha$ and factors that they secondarily induce are potent mediators of cell proliferation, cell differentiation, and programmed cell death (43-45) and could potentially affect developmental processes in the fetus. Whether antigens, antigen-induced cytokines or activated lymphocytes are able to traverse the feto-maternal barrier is still controversial $(26,46)$.

(b) Endotoxemia in humans and animals has been shown to cause fetal death and abortion $(47,48)$ and damage to placental tissue as well $(6,47,49,50)$. These effects of endotoxin could be mimicked by i.p. injection of high doses $(\geq 100 \mu \mathrm{g} / \mathrm{kg})$ of recombinant human IL- $\alpha$ or TNF- $\alpha$ (6). High concentrations of endotoxin (LPS; $\geq 100 \mu \mathrm{g} / \mathrm{kg}$ in rats or guinea pigs; $\geq 5$ $\mu \mathrm{g} /$ mouse) also produce transplacental effects including fetal growth retardation, skeletal anomalies, and increased neuronal necrosis $(47,49,51)$. It has been considered that due to the endotoxin-induced severe placental ischemia, fetal hypoxia may be one of the prime teratogenic mechanisms $(47,50)$. Hypoxia has been shown to cause fetal damage in many species ( 52 , 53). In the present study, only a moderate dose of $E$. coli LPS $(30 \mu \mathrm{g} / \mathrm{kg})$ was used and no fetal growth retardation was observed. Although it is unlikely that this dose would cause placental damage, it cannot be excluded. In addition, maternal fever has been reported to be harmful to the fetal brain (54). LPS as well as HRBC are well-known inducers of fever (10; A. C. E. Linthorst and J. M. H. M. Reul, unpublished observations). Thus, although we did not measure body temperature, a 

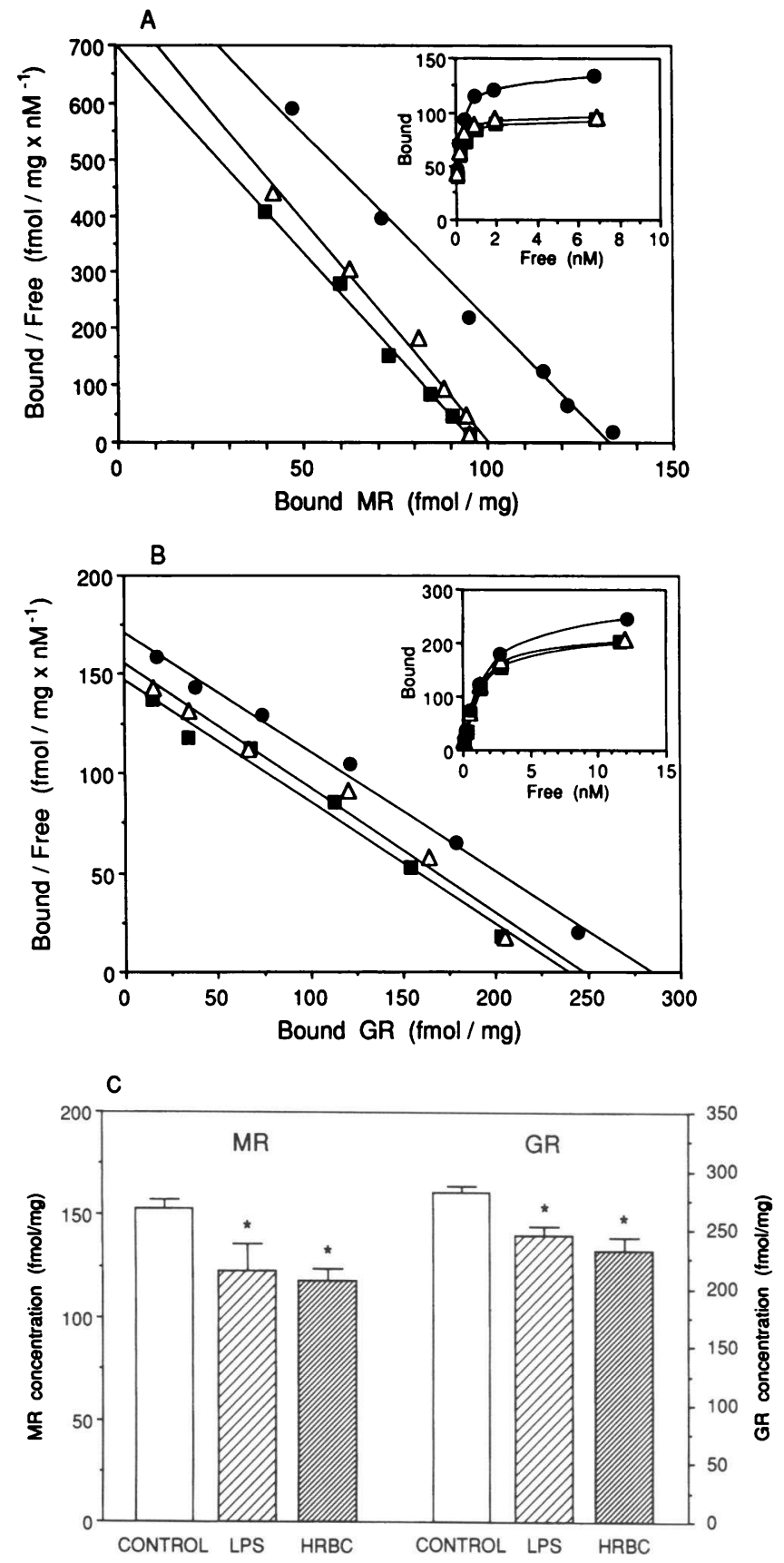

Figure 4. Saturation binding (inset) and Scatchard analysis of MR $(A)$ and GR $(B)$ in hippocampus of LPS and HRBC groups (six animals per group). One representative experiment of a total of three is depicted. The $K_{\mathrm{d}}$ and $B_{\max }$ of hippocampal MR for binding [ $\left.{ }^{3} \mathrm{H}\right]-$ aldosterone were estimated to be $0.15,0.14$, and $0.13(\mathrm{nM})$ and 133 , 96 , and $100(\mathrm{fmol} / \mathrm{mg})$ for the control $(\bullet)$, LPS (๘), and HRBC ( $\Delta)$ groups, respectively. The $K_{\mathrm{d}}$ and $B_{\max }$ of hippocampal GR for $\left[{ }^{3} \mathrm{H}\right]$ dexamethasone binding were estimated to be $1.67,1.62$, and 1.59 (nM) and 285, 240 and 248 (fmol/mg) for the control, LPS, and HRBC groups, respectively. $C$ represents MR and GR measurements in hippocampus tissue of individual animals ( $n=7-8$, mean \pm SEM). Corticosteroid receptors were measured in a soluble binding assay as outlined in Methods. ${ }^{*}, P<0.05$, Duncan multiple range test.

hyperpyretic response in the maternal animals is very likely and may have contributed to the anomalies in fetal brain development.
Table II. Effect of Prenatal Immune Challenges on Hypothalamic and Anterior Pituitary Glucocorticoid Receptors in Adulthood

\begin{tabular}{lccc}
\hline & \multicolumn{3}{c}{ Prenatal treatment } \\
\cline { 2 - 4 } & Control & LPS & HRBC \\
\hline $\begin{array}{l}\text { Hypothalamus } \\
\text { GR }\end{array}$ & $192 \pm 3(5)$ & $197 \pm 3(5)$ & $196 \pm 3(5)$ \\
$\begin{array}{l}\text { Anterior pituitary } \\
\text { GR }\end{array}$ & $181 \pm 2(5)$ & $202 \pm 1(5)^{*}$ & $206 \pm 2(5)^{*}$ \\
\hline
\end{tabular}

GR concentration in hypothalamus and anterior pituitary of male rats treated prenatally with saline, LPS, or HRBC. Determination of GR in hypothalamus and anterior pituitary was done on pooled tissues from eight rats (data represent the mean $\pm S E M$ of five independent experiments). Receptor concentrations are expressed as $\mathrm{fmol} / \mathrm{mg}$ protein. GR was measured in a soluble binding assay as outlined in Methods. ${ }^{*} P<0.05$, Duncan multiple range test.

(c). Immune challenge-induced changes in circulating glucocorticoid and thyroid hormone levels may have affected fetal brain development. Both glucocorticoid (55) and thyroid hormones (56) readily cross the blood-placenta barrier and for many years it has been known that glucocorticoid and thyroid hormones have a profound influence on developmental processes in fetal brain. Prenatal stress has been shown to induce changes in HPA axis activity (57), brain monoamine activity (58), and behavioral paradigms $(59,60)$ in the adult offspring. It has been postulated that increased maternal glucocorticoid secretion underlie these effects $(61,62)$. Injection of rats with xenogeneic erythrocytes markedly elevates plasma corticosterone levels between days 4 and 8 after administration (27), whereas LPS stimulates the HPA system for a much shorter time period: $2-8 \mathrm{~h}$ (29). Such long-term elevations in glucocorticoid hormones levels as occurring after HRBC administration, may have contributed markedly to the developmental disturbances reported in this study.

Deficiencies of thyroid hormones during the so-called "critical period" (in rat from gestational day 18 to $21 \mathrm{~d}$ postpartum) (63) causes irreparable damage to the structural development and organization of the brain (64). In humans, thyroid function is often altered during conditions of severe illness or stress known as the "euthyroid sick syndrome" $(65,66)$. Sick rats show reduced plasma thyroid stimulating hormone (TSH) and $\mathrm{T}_{4}$ levels (67). A decline in thyroid function was also observed after IL- $1 \beta$ administration to rats (68). In our studies, immune stimulation may have depressed maternal thyroid function thereby compromising fetal brain development.

In this study, a most relevant observation was that a $T$ cellmediated immune response (HRBC) during pregnancy appeared to have more severe implications for HPA system regulation in the adult offspring than prenatal administration of an endotoxic agent (LPS). Although both prenatally treated groups showed similar changes in corticosteroid receptor levels in brain and pituitary, the observation that prenatal HRBC rats produced much higher hormonal responses after stress, strongly suggests that distinct neuroendocrine mechanisms, apart from the corticosteroid receptors, are affected by the prenatal immunological and endotoxic challenge. As detailed above, these challenges evoke many pathophysiological changes in the maternal animal. It may be speculated that the 
duration of such antigen-induced responses is determinant for the extent of the neuroendocrine disorder in adult life. Thus, the relatively long-lasting pathophysiological responses after HRBC (time span, days) may have caused more damage to the organization of neural circuitry underlying HPA axis regulation than those after LPS (time span, hours). Such other target mechanisms involved in HPA axis regulation may include the ascending noradrenergic and serotonergic systems innervating limbic brain areas $(69,70)$, and the paraventricular CRH and vasopressin system in the hypothalamus (71). Further studies are required to discern the brain mechanisms underlying the HPA axis disturbances after a prenatal immune challenge. Interestingly, both prenatal LPS and HRBC evoked a significant increase in basal corticosterone values, but no changes were observed in ACTH levels. This observation suggests an increased adrenal sensitivity to ACTH in the prenatally challenged animals, which may involve altered splanchnic neural input to the adrenal (72).

Many preclinical and clinical reports have evidenced that exposure to elevated glucocorticoid levels for prolonged periods of time, as occurring most severely in the prenatally HRBC-treated rats, are ultimately detrimental for the organism. Hypercorticism has been observed to cause immune suppression, steroid diabetes, inhibition of growth, hypertension and infertility (18). Moreover, a disturbed HPA axis regulation seems also to be implicated in the precipitation of psychiatric disease, such as major depression, and patients with Cushing's disease often suffer from changes in mood and affect reminiscent to those observed in major depressive illness $(73,74)$. Treatment of depressed patients with antidepressants has been shown to normalize HPA axis function before clinical improvement was noted (75-77). The correction of Cushing's disease is usually followed by an alleviation of the depressive symptoms (74). In experimental animals, antidepressants have been shown to increase hippocampal expression of $M R$ and GR with parallel reductions in basal and stress-induced ACTH and corticosterone secretion and in adrenal weight (33). Thus, HPA axis dysfunction appears to be associated with an increased vulnerability for mental disease in later live. Furthermore, it is of interest to note that some epidemiological studies have suggested a link between prenatal viral (e.g., Influenzae A2) infections and the pathogenesis of psychiatric illness (78). In addition, pregnant women with fever and bacteriuria due to infection with gram-negative organisms give birth to a higher incidence of children with neurologic defects than do mother free of infection $(79,80)$. The present study demonstrates that during pregnancy a $\mathrm{T}$ cell-mediated immune reponse as well as an endotoxic challenge affect fetal brain development precipitating in a disturbed HPA system function in adulthood. This observation may open up new insights into the involvement of disordered fetal brain development in the pathogenesis of psychiatric disease.

\section{Acknowledgments}

The authors thank Dr. Wolfgang Klinkert for his kind help regarding the whole cell ELISA methodology and Dr. Dan Lindholm for his gift of the rat IL-1 $\beta$ clone. The authors acknowledge the expert technical assistance of Ms. Stefanie Andres and Ms. Monika Söder. The superb secretarial support by Ms. Elfi Fesl is also gratefully acknowledged.

This study was supported by the Volkswagen-Stiftung, Germany, (grant I/68 430).

\section{References}

1. Bland, P. B. Influenza in its relation to pregnancy and labor. 1919. Am. J. Obstet. Dis. Wom. 79:184-197.

2. Graeff, H., W. Kuhn, and J. Zander. 1973. Endotoxin shock in obstetrics. In Gram-negative Bacterial Infections and Mode of Endotoxin Actions. Pathophysiological, Immunological and Clinical Aspects. B. Urbaschek, R. Urbaschek and E. Neter, editors. Springer-Verlag Wein, Vienna. 446-449.

3. Coid, C. R., H. Sandison, G. Slavin, and D. G. Altman. 1978. Escherichia coli infection in mice and impaired fetal development. Br. J. Exp. Path. 59:292297.

4. Chaouat, G., E. Menu, M. Hofman, M. Dy, M. Minkowsky, D. A. Clark and T. G. Wegmann. 1989. Lymphokines at the feto maternal interface affect fetal size and survival. Placenta. 10:482.

5. Guilbert, L., S. A. Robertson, and T. G. Wegmann. 1993. The trophoblast as an integral component of a macrophage-cytokine network. Immunol. Cell Biol. 71:49-57.

6. Silen, M. L., A. Firpo, S. Morgello, S. F. Lowry, and T. Francus. 1989. Interleukin-1 $\alpha$ and tumor necrosis factor $\alpha$ cause placental injury in the rat. $A m$. J. Pathol. 135:239-244.

7. Tartakovsky, B., and O. Goldstein. 1990. The effect of cytokines on pregnancy and embryonic development in mice. In The Physiological and Pathological Effects of Cytokines. C. A. Dinarello, M. J. Kluger, M. C. Powanda, and J. J. Oppenheim, editors. Wiley-Liss, Inc., New York. 243-248.

8. Dinarello, C. A. 1984. Interleukin-1. Rev. Infect. Dis. 6:51-95.

9. Dinarello, C. A. 1988. Biology of interleukin 1. FASEB (Fed. Am. Soc. Exp. Biol.) J. 2:108-115.

10. Kluger, M. J. 1991. Fever: role of pyrogens and cryogens. Physiol. Rev. 71:93-127.

11. Okusawa, S., J. A. Gelfand, F. Ikejima, R. J. Connolly, and C. A. Dinarello. 1988. Interleukin 1 induces a shock-like state in rabbits. J. Clin. Invest. 81:1162-1172.

12. Kushner, I. 1982. The phenomenon of the acute phase response. Ann. $N Y$ Acad. Sci. 389:39-48.

13. Rivier, C., and W. Vale. 1989. In the rat, interleukin- $1 \alpha$ acts at the level of the brain and the gonads to interfere with gonadotropin and sex steroid secretion. Endocrinology 124:2105-2109.

14. Hart, B. L. 1988. Biological basis of the behavior of sick animals. Neurosci. Biobehav. Rev. 12:123-137.

15. Kent, S., R. M. Bluthe, R. Dantzer, A. J. Hardwick, K. W. Kelley, N. J. Rothwell, and J. L. Vannice. 1992. Different receptor mechanisms mediate the pyrogenic and behavioral effects of interleukin 1. Proc Natl. Acad. Sci. USA. 89:9117-9120.

16. Besedovsky, H., A. Del Rey, E. Sorkin, and C. A. Dinarello. 1986. Immunoregulatory feedback between interleukin-1 and glucocorticoid hormones. Science (Wash. DC). 233:652-654.

17. Bateman, A., A. Singh, T. Kral, and S. Solomon. 1989. The immune-hypothalamic-pituitary-adrenal axis. Endocr. Rev. 10:92-112.

18. Munck, A., P. M. Guyre, and N. J. Holbrook. 1984. Physiological functions of glucocorticoids in stress and their relation to pharmacological actions. Endocr. Rev. 5:25-44.

19. Besedovsky, H. O. and A. Del Rey. 1992. Immune-neuroendocrine circuits: integrative role of cytokines. Front. Neuroendocrinol. 13:61-94.

20. Reul, J. M. H. M., and E. R. De Kloet. 1985. Two receptor systems for corticosterone in rat brain: microdistribution and differential occupation. Endocrinology 117:2505-2512.

21. Reul, J. M. H. M., and E. R. De Kloet. 1986. Anatomical resolution of two types of corticosterone receptor sites in rat brain with in vivo autoradiography and computerized image analysis. J. Steroid Biochem. 24:269-272.

22. Van Eekelen, J. A. M., W. Jiang, E. R. De Kloet, and M. C. Bohn. 1988. Distribution of the mineralocorticoid and the glucocorticoid receptor $m$ RNAs in the rat hippocampus. J. Neurosci. Res. 21:88-94.

23. De Kloet, E. R., and J. M. H. M. Reul. 1987. Feedback action and tonic influence of corticosteroids on brain function: a concept arising from the heterogeneity of brain receptor systems. Psychoneuroendocrinology. 12:83-105.

24. De Kloet, E. R. 1991. Brain corticosteroid receptor balance and homeostatic control. Front. Neuroendocrinol. 12:95-164.

25. Rothuizen, J., J. M. H. M. Reul, F. J. Van Sluijs, J. A. Mol, A. Rijnberk, and E. R. De Kloet. 1993. Increased neuroendocrine reactivity and decreased brain mineralocorticoid receptor-binding capacity in aged dogs. Endocrinology 132:161-168.

26. Klein, J. 1982. Responses dominated by T lymphocytes. In Immunology. The Science of Self-Nonself Discrimination. Wiley-Interscience, New York. 445-506.

27. Besedovsky, H. O., E. Sorkin, M. Keller, and J. Müller. 1975. Changes in blood hormone levels during the immune response (39057). Proc. Soc. Exp. Biol. Med. 150:466-470.

28. Yasuda, N., and M. A. Greer. 1978. Evidence that the hypothalamus mediates endotoxin stimulation of adrenocorticotropic hormone secretion. Endocrinology. 102:947-953. 
29. Dunn, A. 1992. Endotoxin-induced activation of cerebral catecholamine and serotonin metabolism: comparison with interleukin-1. J. Pharm. Exp. Ther. 261:964-969.

30. Paxinos, G., I. Törk, L. H. Tecott, and K. L. Valentino. 1991. Atlas of the Developing Rat Brain. Academic Press, London.

31. Chomczynski, P., and N. Sacchi. 1987. Single-step method of RNA isolation by acid guanidinium thiocyanate-phenol-chloroform extraction. Anal. Biochem. 162:156-159.

32. Saambrok, J., E. F. Fritsch, and T. Maniatis. 1989. Molecular Cloning, a Laboratory Manual. Cold Spring Harbor Laboratory Press, New York.

33. Reul, J. M. H. M., I. Stec, M. Söder, and F. Holsboer. 1993. Chronic treatment of rats with the antidepressant amitriptyline attenuates the activity of the hypothalamic-pituitary-adrenocortical system. Endocrinology. 133:312-320.

34. Reul, J. M. H. M., E. R. de Kloet, F. J. van Sluijs, A. Rijnberk, and J. Rothuizen. 1990. Binding characteristics of mineralocorticoid and glucocorticoid receptors in dog brain and pituitary. Endocrinology. 127:907-915.

35. Spencer, R. L., and B. S. McEwen. 1990. Adaptation of the hypothalamicpituitary-adrenocortical axis to chronic ethanol stress. Neuroendocrinology. 52:481-489.

36. Spencer, R. L., E. A. Young, P. H. Choo, and B. S. McEwen. 1990. Adrenal steroid type I and type II receptor binding: estimates of in vivo receptor number, occupancy, and activation with varying level of steroid. Brain Res. $514: 37-48$.

37. Lowry, O. H., N. J. Rosebrough, A. L. Farr, and N. J. Randall. 1951. Protein measurements with the Folin phenol reagent. J. Biol. Chem. 193: 265-275.

38. Mosman, T. R., and R. L. Coffman. 1989. Heterogeneity of Cytokine Secretion Patterns and Functions of Helper T Cells. Adv. Immunol. 46:111-147.

39. Cher, D. J., and T. R. Mosmann. 1987. Two types of murine helper t cell clone. II. Delayed-type hypersensitivity is mediated by $\mathrm{T}_{\mathrm{H}} 1$ clones. J. Immunol. 138:3688-3694.

40. Chaouat, G., E. Menu, D. A. Clark, M. Dy, M. Minkowski, and T. G. Wegmann. 1990. Control of fetal survival in CBA $\times \mathrm{DBA} / 2$ mice by lymphokine therapy. J. Reprod. Fertil. 89:447-458.

41. Fiorentino, D. F., M. W. Bond, and T. R. Mosmann. 1989. Two types of mouse T helper cell. IV. Th2 clones secrete a factor that inhibits cytokine production by Th1 clones. J. Exp. Med. 170:2081-2095.

42. Wegmann, T. G., H. Lin, L. Guilbert, and T. R. Mosmann. 1993. Bidirectional cytokine interactions in the maternal-fetal relationship: is successful pregnancy a $\mathrm{T}_{\mathrm{H}} 2$ phenomenon? Immunol. Today. 14:353-356.

43. Durum, S., and J. J. Oppenheim. 1989. Macrophage-derived mediators: interleukin 1, tumor necrosis factor, interleukin 6, interferon, and related cytokines. In Fundamental Immunology. W. E. Paul, editor. Raven Press, New York. 639-661.

44. Balkwill, F. R., and F. Burke. 1989. The cytokine network. Immunol. Today. 10:299-304.

45. Di Giovine, F. S., and G. W. Duff. 1990. Interleukin 1: the first interleukin. Immunol. Today. 11:13-20.

46. Dahl, G. M., E. Telemo, B. R. Westrom, I. Jakobsson, and B. W. Karlsson. 1984. The passage of orally fed proteins from mother to foetus in the rat. Comp. Biochem. Physiol. 77A:199-201.

47. Ornoy, A., and G. Altshuler. 1976. Maternal endotoxemia, fetal anomalies, and central nervous system damage: a rat model of a human problem. Am. J. Obstet. Gynecol. 124:196-204.

48. Hall, G. A., and P. W. Jones. 1976. An experimental study of Salmonella Dublin abortion in cattle. Br. Vet. J. 132:60-65.

49. Haesaert, B., and A. Ornoy. 1986. Transplacental effects of endotoxemia on fetal mouse brain, bone, and placental tissue. Pediatric Pathol. 5:167-181.

50. Altshuler, G. 1993. Some placental considerations related to neurodevelopmental and other disorders. J. Child Neurol. 8:78-94.

51. Beckmann, I., F. Meisel-Mikolajczyk, P. Leszczynski, M. Brooijmans, and H. C. S. Wallenburg. 1993. Endotoxin-induced fetal growth retardation in the pregnant guinea pig. Am. J. Obstet. Gynecol. 168:714-718.

52. Grabowski, C. T. 1970. Advances in Teratology. Academic Press, Inc. New York. $125 \mathrm{pp}$.

53. Tedeschi, C. G., and T. H. Ingalls. 1956. Vascular anomalies of mouse fetuses exposed to anoxia during pregnancy. Am. J. Obstet. Gynecol. 71:16-28.

54. Edwards, M. J., R. H. C. Penny, and I. Zevnik. 1971. A brain cell deficit in newborn guinea-pigs following prenatal hyperthermia. Brain Res. 28:341-345.

55. Zarrow, M. X., J. E. Philpott, and V. H. Denenberg. 1970. Passage of ${ }^{14} \mathrm{C}-4$-corticosterone from the rat mother to the foetus and neonate. Nature (Lond.). 226:1058-1059.

56. Morreale de Escobar, G., M. J. Obregon, and F. Excobar del Rey. 1988. Transfer of thyroid hormones from the mother to the fetus. In Research in Con- genital Hypothyroidism. F. Delang, D. A. Fisher, and D. Glinoer, editors. Plenum Press, New York. 15-28.

57. Takahashi, L. K., N. H. Kalin, C. M. Barksdale, and P. Van den Burgt. 1988. Stressor controllability during pregnancy influences pituitary-adrenal hormone concentrations and analgesic responsiveness in offspring. Physiol. Behav. 42:323-329.

58. Moyer, J. A., L. R. Herrenkohl, and D. M. Jacobowitz. 1978. Stress during pregnancy: effect on catecholamines in discrete brain regions of offspring as adults. Brain Res. 144:173-178.

59. Ader, R., and R. M. Conklin. 1963. Handling of pregnant rats: effects on emotionality of their offspring. Science (Wash. DC). 142:411-412.

60. Ward, I. L. 1972. Prenatal stress feminizes and demasculinizes the behavior of males. Science (Wash. DC). 175:82-84.

61. Joffe, J. M. 1978. Hormonal mediation of the effects of prenatal stress on offspring behavior. In Studies on the Development of Behavior and the Nervous System: Early Influences, Vol. 4. G. Gottlieb, editor. Academic Press, New York. $108-144$.

62. Wilke, D. L., S. R. Tseu, R. W. Rhees, and D. E. Fleming. 1982. Effects of environmental stress or ACTH treatment during pregnancy on maternal and fetal plasma androstenedione in the rat. Hormones and Behav. 16:293-303.

63. Dussault, J. H., and J. Ruel. 1987. Thyroid hormones and brain development. Annu. Rev. Physiol. 49:321-334.

64. Porterfield, S. P., and C. E. Hendrich. 1993. The role of thyroid hormones in prenatal and neonatal neurological development-current perspectives. Endocr. Rev. 14:94-106.

65. Wartofsky, L., and K. D. Burman. 1982. Alterations in thyroid function in patients with systemic illness: the "euthyroid sick syndrome." Endocr. Rev. 3:164-217.

66. Burger, A. G., and R. Davies. 1985. Euthyroid low $\mathrm{T}_{3}$ states. In Pediatric Thyroidology: Pediatric Adolescent Endocrinolology, Vol. 14. F. Delange, D. A Fisher, and P. Malvaux, editors. Karger, Basel. 327-344.

67. Burger, A. G., J.-N. Hugues, and E. Saville. 1981. Starvation and thyroid function: effects on thermogenesis and serum thyrotropin. Life Sci. 28:17371744.

68. Dubuis, J.-M., J.-M. Dayer, C. A. Siegrist-Kaiser, and A. G. Burger. 1988 Human recombinant interleukin- $1 \beta$ decreases plasma thyroid hormone and thyroid stimulating hormone levels in rats. Endocrinology. 123:2175-2181.

69. Tuomisto, J., and P. Männisto. 1985. Neurotransmitter regulation of anterior pituitary hormones. Pharmacol. Rev. 37:249-332.

70. Sawchenko, P. E., L. W. Swanson, H. W. M. Steinbusch, and A. A. J. Verhofstad. 1993. The distribution and cells of origin of serotonergic inputs to the paraventricular and supraoptic nuclei of the rat. Brain Res. 277:355-360.

71. Swanson, L. W. 1987. The hypothalamus. In Handbook of Chemical Neuroanatomy, Vol. 5: Integrated Systems of the CNS, Part I. A. Björklund, T. Hökfeld, and L. W. Swanson, editors. Elsevier Science Publishers B. V., Amsterdam. 1-124.

72. Jasper, M. S., and Engeland, W. C.. 1993. Splanchnicectomy alters diurnal sensitivity to ACTH and abolishes diurnal rhythmicity in corticosterone secretion in awake rats. Proceedings of the 23rd Annual Meeting Society for Neuroscience, Washington D.C. 1188.

73. Holsboer, F. 1992. The hypothalamic-pituitary-adrenocortical system. In Handbook of Affective Disorders. E. S. Paykel, editor. Churchill Livingstone/ Edinburgh. 267-287.

74. Checkley, S. 1992. Neuroendocrine mechanisms and the precipitation of depression by life events. Br. J. Psychiatry. 160 (suppl. 15):7-17.

75. Holsboer, F., R. Liebl, and E. Hofschuster. 1982. Repeated dexamethasone suppression test during depressive illness. Normalization of test result compared with clinical improvement. J. Affective Disord. 4:93-101.

76. Greden, J. F., R. Gardner, D. King, L. Grunhaus, B. J. Carroll, and Z. Kronfold. 1983. Dexamethasone suppression tests in antidepressant treatment of melancholia-the process of normalization and test-retest reproductibility. Arch. Gen. Psychiatry. 40:493-500.

77. Holsboer-Trachsler, E., R. Stohler, and M. Hatzinger. 1991. Repeated administration of the combined dexamethasone/hCRH stimulation test during treatment of depression. Psychiatry Res. 38:163-171.

78. O’Callaghan, E., P. Sham, N. Takei, G. Glover, and R. M. Murray. 1991 Schizophrenia after prenatal exposure to 1957 A2 influenza epidemic. Lancet 137:1248-1250.

79. Patrick, M. J. 1967. Influence of maternal renal infection on the foetus and infant. Arch. Dis. Child. 42:208-213.

80. Niswander, K. R., and M. Gordon. 1972. The Women and Their Pregnancies. The Collaborative Perinatal Study of the National Institute of Neurological Diseases and Stroke. W. B. Saunders Company, Philadelphia, PA. 252-256. 